\title{
A Review of the "Omics" Approach to Biomarkers of Oxidative Stress in Oryza sativa
}

\author{
Nyuk Ling Ma ${ }^{1, *}$, Zaidah Rahmat ${ }^{2}$ and Su Shiung Lam ${ }^{3}$
}

1 Department of Biology, Faculty of Science and Technology, University Malaysia Terengganu, 21030 Kuala Terengganu, Terengganu, Malaysia

2 Department of Biotechnology and Medical Engineering, Faculty of Biosciences and Medical Engineering, University Technology Malaysia, 81310 Johor Bahru, Johor, Malaysia; E-Mail: zaidah@fbb.utm.my Department of Engineering Science, Faculty of Science and Technology, University Malaysia Terengganu, 21030 Kuala Terengganu, Terengganu, Malaysia; E-Mail: lam@umt.edu.my

* Author to whom correspondence should be addressed; E-Mail: nyukling@umt.edu.my; Tel.: +609-668-3845; Fax: +609-668-3326.

Received: 31 January 2013; in revised form: 20 March 2013 / Accepted: 20 March 2013 / Published: 8 April 2013

\begin{abstract}
Physiological and ecological constraints that cause the slow growth and depleted production of crops have raised a major concern in the agriculture industry as they represent a possible threat of short food supply in the future. The key feature that regulates the stress signaling pathway is always related to the reactive oxygen species (ROS). The accumulation of ROS in plant cells would leave traces of biomarkers at the genome, proteome, and metabolome levels, which could be identified with the recent technological breakthrough coupled with improved performance of bioinformatics. This review highlights the recent breakthrough in molecular strategies (comprising transcriptomics, proteomics, and metabolomics) in identifying oxidative stress biomarkers and the arising opportunities and obstacles observed in research on biomarkers in rice. The major issue in incorporating bioinformatics to validate the biomarkers from different omic platforms for the use of rice-breeding programs is also discussed. The development of powerful techniques for identification of oxidative stress-related biomarkers and the integration of data from different disciplines shed light on the oxidative response pathways in plants.
\end{abstract}

Keywords: biomarker; stress signaling; "omic" study; metabolomic; proteomic; transcriptomic 


\section{Introduction}

Rice is still a staple food in many countries [1]. An increase in the human population places a great deal of pressure on the agriculture sector [2,3], in which the production of the rice can no longer fulfill worldwide demands [4]. In addition, the full yield potential of rice cannot be achieved due to environmental constraints such as temperature, drought, salinity, osmotic stress, etc. The relationship between rice and its environmental changes has been extensively studied in order to tackle the most important agronomical traits for sustainable rice production. It is believed that molecular studies that integrate pillars of proteins, metabolites, and transcripts play an indispensable role in the era of functional genomics. Interestingly, a key feature that stands out over all the general perspectives on plant's response to stress is the enhanced production of reactive oxygen species (ROS), especially the production of hydrogen peroxide $\left(\mathrm{H}_{2} \mathrm{O}_{2}\right)$ within sub-cellular compartments of the plant cell [5]. $\mathrm{H}_{2} \mathrm{O}_{2}$ is a more important secondary messenger than other ROS due to its relatively longer half-life and the fact that it is a small molecule, thus enabled to be transported through different cell compartments [6].

The production of $\mathrm{H}_{2} \mathrm{O}_{2}$ in plant functions as a double-edged sword: the basal level of $\mathrm{H}_{2} \mathrm{O}_{2}$ is important to maintain routine metabolic activities [7], whilst overproduction of $\mathrm{H}_{2} \mathrm{O}_{2}$ could lead to oxidative damage and kill the cells [8]. $\mathrm{H}_{2} \mathrm{O}_{2}$ involves in a number of signaling cascades in plants under stress conditions [9], acting as a defense signaling response to pathogen elicitors [10,11], triggering mitogen-activated protein (MAP) kinase and stomatal response [12,13], and initiating programmed cell death $[14,15]$. In extreme stress conditions, excess ROS accumulated in plant can lead to uncontrolled oxidative stress on DNA [16]. ROS can cause a DNA strand to break by modification either at deoxyribose sugar or at purine and pyrimidine bases [17]. The damage of DNA leads to the reduction of protein synthesis, and this contributes to the destruction of cell membrane and damage to photosynthetic proteins [18]. ROS can oxidize cysteine, tyrosine, tryptophan, histamine, and methionine [19]. Most of the protein oxidation reactions are irreversible [20] and only a few of which involve sulfur-containing amino acids are reversible [21]. The rapid and reversible modification reactions of a protein appears to be an ideal candidate for a signaling event, e.g., cysteine reacts only with $\mathrm{H}_{2} \mathrm{O}_{2}$ [19] that gives rise to different modified products and results in activation of different sets of genes [22]; the oxidation of thiol residues of tyrosine dephosphorylation has been proved to mediate the signaling event in order to avoid programmed cell death caused by severe stress [23]. The sulfonic acid oxidation and carbonylation appear to be the most commonly occurring irreversible oxidative protein modification [24]. The $\mathrm{OH} \bullet$ radical reacts with arginine, histamine, lysine, proline, threonine, and tryptophan and produces nearly $4 \mathrm{nmol} / \mathrm{mg}$ of carbonyl groups in stressed plant [25]. A higher concentration of carbonyl groups has been reported in senescence leaf, recording a concentration of approximately $600-700 \mathrm{nmol} / \mathrm{mg}$ in pea [26]. ROS has also been reported to have caused massive damage to the lipid group by reacting with the olefinic group and removing the allylic hydrogen atom in order to produce lipid peroxy radical. This leads to the breakdown of PUFA and in turn causes secondary damage to plant cells [19]. The adventitious peroxidation of neighboring unsaturated lipids by these radicals weakens the membrane fluidity, hence increasing the leakiness of membrane and leading to secondary damage to membrane proteins [19]. Moderate oxidative stress usually stops the cell cycle, but severe damage might trigger death by apoptosis, necrosis, or both [7]. Even though abiotic stresses have been shown to cause reduction in rice yield [27], the direct effects of ROS that 
lead to this depletion have not yet been reported. This is because the baseline level of $\mathrm{H}_{2} \mathrm{O}_{2}$ production often varies in different plant species and the complexity changes that occur under stress conditions have made it difficult to draw any conclusions [28]. Nevertheless, $\mathrm{H}_{2} \mathrm{O}_{2}$ has been reported to react with plant cells and it would leave traces of biomarkers at the genome, proteome and metabolome levels. In research studies, biomarkers can be employed to reflect the environmental pro-oxidant exposures and the antioxidants levels that serve as a surrogate measurement of the cellular status under certain stress condition. To date, the progress in the understanding of the oxidative stress mechanism in plant (particularly in rice) has been slow and frustrating due to the complex and heterogeneous nature of the oxidative molecule function in plant cells. The limited information available on oxidative molecule function has restricted the progress towards the improvement of crop production. Therefore, a close investigation into biomarkers for oxidative stress response could give a potential clue on how plant responses toward stress also provide early detection of ROS. In addition, stress biomarkers could reveal a suitable genes candidate for rice plant improvement. This review highlights the difficulties associated with identification of stress biomarkers, and the recent progress in "omics" technology towards the identification of biomarker in rice.

\section{Cellular Sources and Regulation of ROS}

In the plant system, the majority of the ROS is generated from energy transfer during photosynthesis. When a plant is exposed to light, $\mathrm{H}_{2} \mathrm{O}_{2}$ is produced via the Mehler reaction in chloroplasts (1) and electron transport in peroxisomes (3) (Figure 1). Photorespiration in mitochondria (2) appears to be the main ROS producer for plants that were kept in darkness [29,30]. It was estimated that every $1 \%-5 \%$ of the $\mathrm{O}_{2}$ consumed contributed to ROS production [31]. ${ }^{1} \mathrm{O}_{2}$ is a natural byproduct of photosynthesis in photosystem II (PSII), even under low light conditions. The photosynthetic electron transfer chain (ETC) is responsible for the production of $\mathrm{H}_{2} \mathrm{O}_{2}$. ETC components include a number of enzymes on the reducing side of photosystem I (PSI), namely: Fe-S center, reduced thioredoxin (TRX), and ferredoxin. Later studies have also suggested that the acceptor side of the electron transfer chain (ETC) in PSII provides electron leakage that changes $\mathrm{O}_{2}$ to $\mathrm{O}_{2}{ }^{-}$(Figure 1). $\mathrm{H}_{2} \mathrm{O}_{2}$ is then produced either through dismutation of $\mathrm{O}_{2}{ }^{--}$by superoxide dismutase enzymes (SOD) or through the reduction of superoxide using reductants such as ascorbate (ASA), thiols, and ferredoxins [32]. The reduction of $\mathrm{H}_{2} \mathrm{O}_{2}$ to $\mathrm{H}_{2} \mathrm{O}$ is achieved by oxidation of ASA to monodehydroascorbate radical (MDHA), which is catalyzed by ascorbate peroxidase (APX). The MDHA is subsequently reduced back to ASA by either ferredoxin reduction or NAD(P)H catalyzed chloroplastic MDHAR [33]. In peroxisomes, the main event occurred is photorespiration whereby $\mathrm{O}_{2}{ }^{--}$ radicals are produced as a consequence of their normal metabolism. MDHAR mediates the formation of $\mathrm{O}_{2}{ }^{--}$in the peroxisome ETC, which is comprised of flavoprotein NADH and cytochrome $b$ [34]. The main process that generates $\mathrm{H}_{2} \mathrm{O}_{2}$ in peroxisomes is via the enzymatic reaction of flavin oxidases $[34,35]$. The photorespiratory pathway appears to be a faster process to generate $\mathrm{H}_{2} \mathrm{O}_{2}$ compared to the Mehler reaction and electron transport in mitochondria [29]. Plant mitochondria act as an energy factory that contributes to the major production site of ROS [36]. The production of $\mathrm{O}_{2}{ }^{--}$ occurs mainly at two sites of the electron transport chain: NAD(P)H dehydrogenases (Complex I) and the cytochrome $b c 1$ complex (Complex III) [31]. The mitochondria component in plants differs from 
that in animals with specific ETC components that function in photorespiration. The ETC harbors electrons with sufficient free energy in order to directly reduce $\mathrm{O}_{2}$ in aerobic respiration. The superoxide anion then forms $\mathrm{H}_{2} \mathrm{O}_{2}$ via the reaction of mitochondrion-specific manganese SOD (Mn-SOD) [31]. The amount of $\mathrm{H}_{2} \mathrm{O}_{2}$ produced in plant mitochondria is less than that produced in chloroplasts or peroxisomes when the plant is exposed to light [29], while it appears to be a major ROS production site in the dark [37]. $\mathrm{H}_{2} \mathrm{O}_{2}$ reacts with reduced $\mathrm{Fe}^{2+}$ and $\mathrm{Cu}$ (produced from Fenton/Haber-Weiss reaction) to form reactive $\mathrm{HO} \cdot$ that can penetrate cell membranes and travel in the cell [37].

Figure 1. Biosynthesis of reactive oxygen species (ROS) and its regulation pathways in plant cells. The production and detoxification of ROS by various enzymatic pathways are shown. (1) The Fenton-Harber-Weiss cycle detoxifies $\mathrm{O}_{2}{ }^{--}$and $\mathrm{H}_{2} \mathrm{O}_{2}$ and alternative oxidase $(\mathrm{AOX})$ reduces the production rate of $\mathrm{O}_{2}^{-{ }^{-}}$in thylakoids. In some plants, iron superoxide dismutase (FeSOD) might replace CuZnSOD in the chloroplast. $\mathrm{H}_{2} \mathrm{O}_{2}$ that escapes this cycle undergoes detoxification by SOD and the stromal ascorbate-glutathione cycle. Peroxiredoxin (PrxR) and glutathione peroxidase (GPX) are also involved in $\mathrm{H}_{2} \mathrm{O}_{2}$ removal in the stomata. (2) In mitochondria, SOD and other components of the ascorbate-glutathione cycle are induced following the production of $\mathrm{H}_{2} \mathrm{O}_{2}$. (3) In peroxisomes, ROS are scavenged by SOD, catalase (CAT), and ascorbate peroxidase (APX). The over-production of $\mathrm{H}_{2} \mathrm{O}_{2}$ is also generated and accumulated via (I) Plasma membrane-localized NADPH oxidase, (II) cell wall peroxidases, (III) germin-like oxalate oxidases, and (IV) amine oxidases. The NADPH-dependent oxidase system catalyzes the production of superoxide by reducing one oxygen electron using NADPH as a donor. The superoxide that is generated by this enzyme then converts to $\mathrm{H}_{2} \mathrm{O}_{2}$. Although the pathways in the different compartments are mostly separated from each other, $\mathrm{H}_{2} \mathrm{O}_{2}$ can easily diffuse through membranes, and antioxidants such as glutathione and ascorbic acid (reduced or oxidized) can be transported between the different compartments.

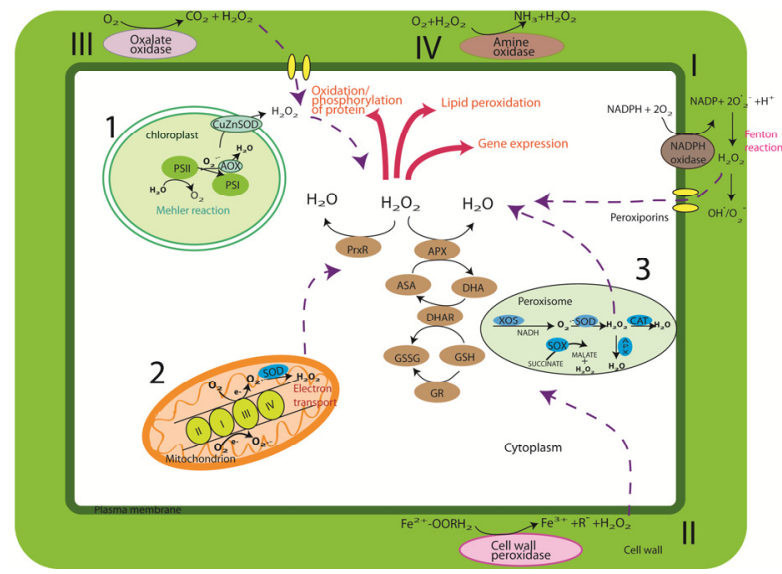

Apart from the normal routes discussed above, ROS is also generated and accumulated via plasma membrane localized NADPH oxidase (I) and cell wall peroxidase (III) (Figure 1) [38]. The NADPH-dependent oxidase system catalyzes the production of superoxide by reducing one oxygen electron using NADPH as a donor. The superoxide that is generated by this enzyme then converts to 
$\mathrm{H}_{2} \mathrm{O}_{2}$. Biotic stress also increases $\mathrm{H}_{2} \mathrm{O}_{2}$ generation via the reaction of $\mathrm{pH}$-dependent cell wall peroxidases (II), germin-like oxalate oxidases (III), and amine oxidases (IV) (Figure 1) [10]. Upon exposure to biotic stress, alkalinization of apoplast-activated cell wall peroxidase and the production of $\mathrm{H}_{2} \mathrm{O}_{2}$ is elicited [10].

\section{Genomics of Rice}

The initial strategy to improve crop production involves transformation of useful antioxidant genes into crop in an effort to produce stress tolerance plants (Table 1). However, it was found that common antioxidants are not suitable for all types of stress and hence stress-specific traits are needed to effectively target the different stress signaling pathways. Global analysis of transcription levels in rice plants under different abiotic stresses and in different organs have been intensively studied; a few examples include high salinity [39], drought [40], high temperature [41], cold and $\mathrm{H}_{2} \mathrm{O}_{2}$ [42], and light [43]. However, in natural conditions, rice is exposed to various stresses simultaneously and, therefore, the responses toward stress adaptation are expected to be different compared to those exposed to single stress condition. Rabbani et al. [44] has proved the existence of significant crosstalk between stress-signaling pathways in their research on gene transcription integration under the combined treatment of cold, drought, salinity, and abscisic acid. Since then, numerous stress-induced genes have been identified and their functions are illustrated in Figure 2. The complex stress regulatory system is controlled by ABA divergent patterns. Dehydration-responsive element binding protein (DREB2) and NAC are examples of ABA-independent TFs [45,46], whereas the ABA-responsive element (ABRE) binding protein factor $(\mathrm{ABF})$ functions in ABA-dependent gene expression [47]. In rice, five DREB cDNAs were identified, namely: OsDREB1A, OsDREB1B, OsDREB1C, OsDREB1D, and OsDREB2A [48]; OsDREB1A and OsDREB1B were found to be induced by cold stress while OsDREB2A was found to have the ability to regulate salt and drought stress [48]. Overexpression of OsDREB1A in rice could induce expression of DRE/CRT genes. It has been reported that the OsDREB1A overexpression lines show phenotypes similar to AtDREB1A (Arabidopsis) overexpression line, but with improved stress tolerance [48]. 
Table 1. ROS-scavenging enzymatic antioxidants and their roles in transgenic rice for abiotic stress tolerance.

\begin{tabular}{|c|c|c|c|}
\hline Gene & Source & Response & Reference \\
\hline \multicolumn{4}{|c|}{ Superoxide dismutase (SOD) } \\
\hline $\mathrm{Cu} / \mathrm{Zn} \mathrm{SOD}$ & $\begin{array}{l}\text { Avicennia } \\
\text { marina }\end{array}$ & $\begin{array}{c}\text { Transgenic plants were more tolerant to methyl viologen (MV)-mediated oxidative stress, salinity, and } \\
\text { drought stress. }\end{array}$ & [49] \\
\hline Mn SOD & $\begin{array}{c}\text { Pisum } \\
\text { sativum }\end{array}$ & $\begin{array}{c}\text { Electrolyte content declined and less injury observed in leaf discs of transgenic plants compared to that } \\
\text { observed in wild type plants following treatment with polyethylene glycol (PEG). }\end{array}$ & {$[50]$} \\
\hline Mn SOD & Yeast & $\begin{array}{l}\text { Transgenic plants maintained high level of SOD and ascorbate peroxidise activity in chloroplast upon exposure } \\
\text { to salt stress, while decrease in SOD activities was observed in wild type plants. }\end{array}$ & {$[51]$} \\
\hline \multicolumn{4}{|c|}{ Catalase (CAT) } \\
\hline CAT KatE & E.coli & $\begin{array}{c}\text { Transgenic rice plants showed at least } 1.5-2.5 \text { fold increase of CAT upon exposure to salt stress. The } \\
\text { transgenic rice can survive for another } 14 \text { days compared to wild type plants following treatment with } \\
\text { salt stress. }\end{array}$ & {$[52]$} \\
\hline CAT & $\begin{array}{l}\text { Triticum } \\
\text { aestivum L. }\end{array}$ & $\begin{array}{l}\text { In } 5{ }^{\circ} \mathrm{C} \text { of cold stress, CAT was found } 4-15 \text { times higher in transgenic plants compared to that observed in } \\
\text { wild type plants with very low levels of } \mathrm{H}_{2} \mathrm{O}_{2} .\end{array}$ & {$[53]$} \\
\hline CAT & Suaeda salsa & $\begin{array}{c}\text { Co-expression of CAT and GST resulted in the increment of SOD and CAT activities following treatment with } \\
\text { salt and paraquat stress, while GST activity only increased upon treatment with paraquat stress. } \mathrm{H}_{2} \mathrm{O}_{2} \text {, } \\
\text { malondialdehyde, and electrolyte leakage were found to decrease in transgenic rice compared to wild } \\
\text { type plants. }\end{array}$ & [54] \\
\hline \multicolumn{4}{|c|}{$\begin{array}{ll}\text { Ascorbate peroxidase } \\
\end{array}$} \\
\hline \multicolumn{4}{|l|}{ Knockdown } \\
\hline $\begin{array}{l}\text { OsAPxl and } \\
\text { OsAPx2 }\end{array}$ & Rice & Compensation of ascorbate peroxidase by other peroxidases, including glutathione peroxidase (GPX). & [55] \\
\hline OsAPXa & Rice & Transgenic plants maintained $\mathrm{H}_{2} \mathrm{O}_{2}$ and malondialdehyde (MDA) content when subjected to cold stress. & [56] \\
\hline $\begin{array}{l}\text { Silencing } \\
\mathrm{APx} 1 / 2 \mathrm{~s}\end{array}$ & Rice & Upregulation of other peroxidases was observed under salinity, heat, high light, and MV treatment. & [55] \\
\hline \multicolumn{4}{|c|}{ Glutathione reductase } \\
\hline GR & $\begin{array}{c}\text { Brassica } \\
\text { campestris }\end{array}$ & $\begin{array}{l}\text { High expression of GR improved the protection against photo-bleaching of chlorophyll and photo-oxidative } \\
\text { action of MV in thylakoid membranes at } 25^{\circ} \mathrm{C} \text {. } \\
\text { Glutathione } S \text {-transferases }\end{array}$ & {$[57]$} \\
\hline
\end{tabular}


Table 1. Cont

\begin{tabular}{|c|c|c|c|}
\hline Gene & Source & Response & Reference \\
\hline \multicolumn{4}{|c|}{ Glutathione $S$-transferases } \\
\hline GST & Rice & $\begin{array}{l}\text { Seedlings of the transgenic lines grown under submergence demonstrated enhanced germination and growth } \\
\text { rates at low temperature. }\end{array}$ & [58] \\
\hline OsGSTL1 & Rice & $\begin{array}{l}\text { The overexpression lines showed an increase in GST and GPX activities, and a decrease in the level of } \\
\text { superoxide was observed. }\end{array}$ & [59] \\
\hline GST & Suaeda salsa & Salt and paraquat stress tolerance were observed due to GST, CAT, and SOD activity. & [54] \\
\hline
\end{tabular}

Figure2. Transcription regulatory and gene expression networks of abiotic stress signals.

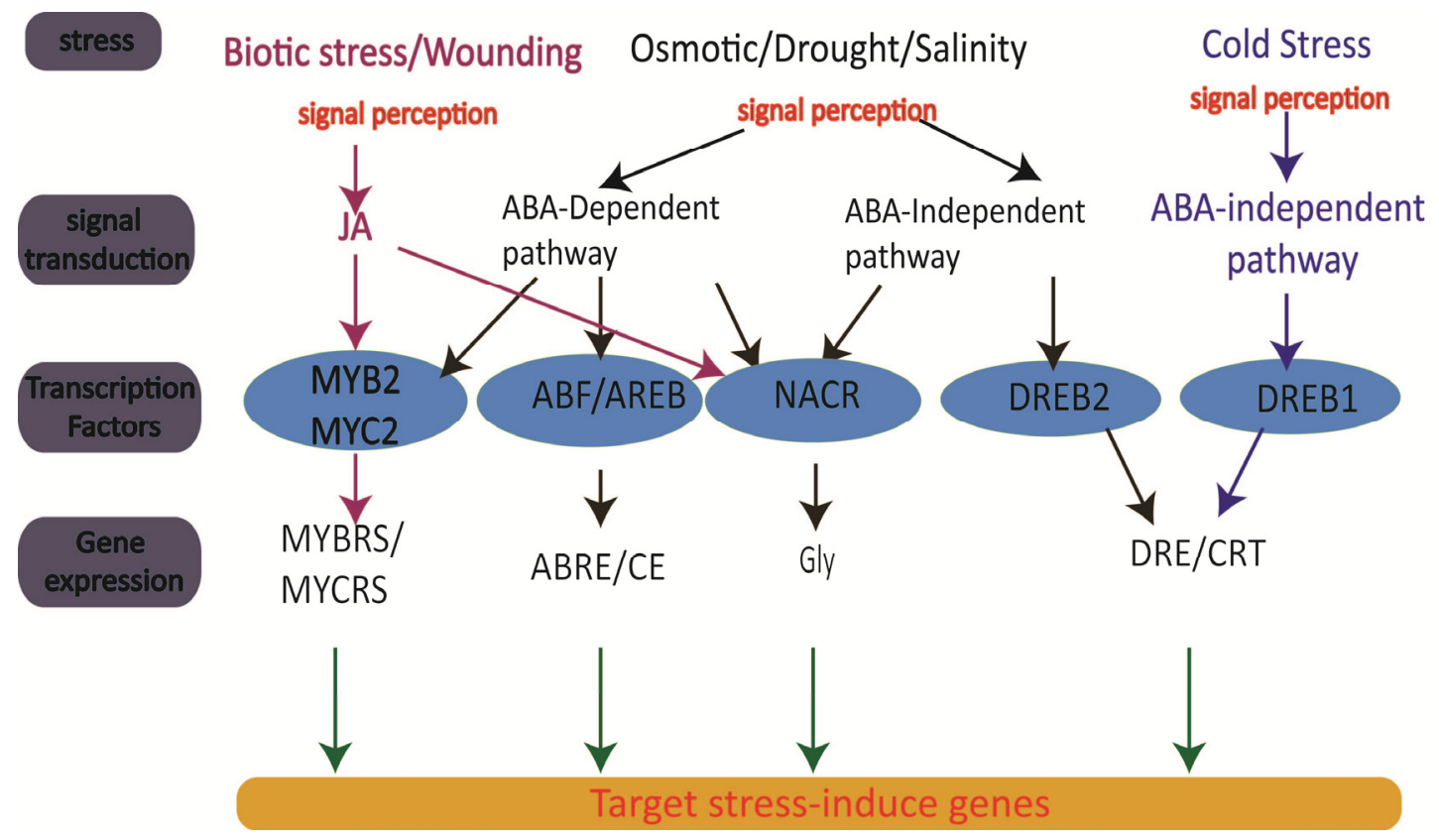


There are 75 putative $N A C$ genes in rice and these genes are mainly involved in regulating plant development and stress tolerance [60]. Salt and drought stress were found to induce ERDI expression via the ABA-independent pathway and they were recognized as $N A C R$ transcription factors [45]; this has been confirmed by Hu et al. [61], who have shown drought and salinity tolerance when the NAC genes were overexpressed. In addition to drought and salinity stress, Ohnishi et al. [62] have reported that OsNAC6, a member of $N A C$ family, was induced under salinity, drought, cold, and ABA. Using the salt tolerant indica variety Nona Bokra versus to salt sensitive japonica variety Koshihikari, Skc1, loci for shoot $\mathrm{K}^{+}$content that it involves in $\mathrm{K}^{+} / \mathrm{Na}^{+}$homeostasis under salt stress, was demonstrated to confer salt tolerance at the seedling stage [63].

Three MYB transcription factors, i.e., MYBS1, MYBS2, and MYBS3, each with a single DNA-binding domain (1R MYB), were identified in rice and they were found to have bound specifically to the TATA box (TATCCA) in the sugar response complex (SRC) of the a-amylase gene (aAmy3) promoter [64]. The MYBS3 in rice is activated by cold stress [65], abscisic acid (ABA), $\mathrm{CdCl}_{2}$, and $\mathrm{NaCl}$ [66]. In addition to these major pathways, MYB/MYC regulons have been reported to be involved in gene expression in wounding and biotic stress.

It has been reported in a study performed on Arabidopsis [67] that the transcription factors that are induced under oxidative stress show many similarities to that induced under ozone stress in rice plant [68], in which WRK, ERF (subfamily of DREB TF), NAM (NAC TF family), and MYB were identified. However, the transcription factors' responses towards oxidative stress vary with different types of ROS. ${ }^{1} \mathrm{O}_{2}$ represents the largest fraction of ROS-related genes while $\mathrm{H}_{2} \mathrm{O}_{2}$ and $\mathrm{O}_{2}{ }^{--}$responsive transcripts are mainly repressed [67]. To date, the ROS sensors and the signaling components that are responsible for this selectivity and specificity within the cell remains a major challenge. Using quantitative trait loci (QTL) analysis, Subl locus that confers to submergence tolerance has been identified [69]. Three genes cluster, i.e., Sub1A, Sub1B, and Sub1C, that encode putative ethylene response factors were observed and only $S u b 1 A$ is variably present in the $S u b 1$ region. The two alleles that control the submergence ability, i.e., Sub1A-1 and Sub1A-2, were identified. Overexpression of SublA-1 in submergence intolerance variety has demonstrated an enhanced tolerance to the plants.

The key research on genetic expression profile during oxidative stress in rice cultivar has been performed by using Affymetrix GeneChip Analysis [70]. A group of marker genes such as glutathione $S$-transferases (GSTs), P450, plant defense genes, and chalcone synthase (CHS) have been identified to play a role in oxidative stress mechanism.

\section{Rice Proteomics}

The analysis of a protein is the most direct approach to define the function of its associated genes. However, it must be mentioned that the genome and proteome of an organism do not always correspond to each other on a one-to-one basis [71,72]. Therefore, the analysis performed at the proteome and metabolome levels are equally important as the genomic study. The function of stress-induced proteins has been expanded by proteomic analysis in different tissues and organelles of rice plant, such as embryos [73], mitochondria [74], roots [75,76], leaves [77], anthers [78] and cell-suspension cultures [79]. A system for direct identification of proteins by differential display following 2-DE has been developed and the structure of the proteins can be identified either by 
comparison with the Rice Proteome Database (http://gene64.dna.affrc.go.jp/RPD/main.html), or by MS and Edman sequencing.

The major finding reported for protein markers of plant stress in rice, especially those that are sensitive to different stresses, are listed in Table 2. In addition to the antioxidants and redox group proteins that are expected to be identified in stressed plant, another protein group that functions in energy metabolism stands out as it seems to be activated almost in every stress. According to Cai and $\mathrm{Tu}$ [80], the proper regulation of the TCA cycle is very important in order to ensure a balance supply of energy to the building blocks of a cell. Therefore, the breaking of the normal energy metabolism is expected to interrupt the development of the cell, and the plant would have to undergo energy reserved state for survival. It was found that the recent proteomic studies in rice have so far focused on the identification of individual polypeptides based on their abundance when subjected to the treatment of different stresses (Table 2). The data of these complex physiological responses were found to vary over the time and stress degree, thus making the data comparison and the proteome integration analyses difficult to be performed between stress treatments. Hereafter, post-translational modification (PTM) such as phosphorylation and thiol modification caused by stress factors could be an alternative study to investigate stress signaling functions. Several strategies have been developed to identify PTM in plants. In particular, the development of 2D-PAGE technology coupled with the application of 5'-iodoacetamidofluorescein (5'IAF) [81,82] or MS such as in 2D-fluorescense difference gel electrophoresis (DIGE) [83] enables the identification of stress-related oxidized and reduced proteins. Many gel-free proteomic systems have also been developed for differential proteome analysis. Examples are multidimensional protein identification methods (MudPIT) that effectively identify individual components of proteins or peptides by avoiding band broadening for chromatographic detection [84], isotope-coded affinity tags (ICAT) [85], and isobaric tags for relative and absolute quantification (iTRAQ). These techniques are considered a targeted method to identify modification in proteins by means of the mass differences between treated and untreated proteomes. Nevertheless, limited studies have been performed on PTMs in plants due to: (1) the difficulties in applying the technique to plants, owing to the need of a large amount of protein for a reaction; (2) the changes of PTMs that often occur at different stages of growth and development, thus making it hard to detect; and, (3) the changing of proteins, which is detected as mass changes, requires complicated processing to transform these data into meaningful information.

Table 2. The change of protein profile stimulated by diversity of abiotic stress.

\begin{tabular}{|c|c|c|c|}
\hline Genotype & Treatment & Major result & Reference \\
\hline $\begin{array}{c}\text { Oryza sativa } \\
\text { L. } \\
\text { cv CT9993 } \\
\text { and } \\
\text { cv IR62266 }\end{array}$ & Drought & $\begin{array}{c}\text { Signal transduction:Translation elongation factor, actin } \\
\text { depolymerizing factor } \\
\text { Energy metabolism: ribulose-1, 5-bisphosphate } \\
\text { carboxylase/oxygenase (RuBisCo) activase, Triosephosphate } \\
\text { isomerase } \\
\text { Antioxidant: superoxide dismutase (SOD), GSH-dependent } \\
\text { dehydroascorbate reductase, } \\
\text { Unknown function: } S \text {-like RNase homolog, isoflavone } \\
\text { reductase-like protein }\end{array}$ & [77] \\
\hline
\end{tabular}


Table 2. Cont.

\begin{tabular}{|c|c|c|c|}
\hline Genotype & Treatment & Major result & Reference \\
\hline $\begin{array}{l}\text { Oryza sativa } \\
\quad L . \\
\text { Nipponbare } \\
\text { Zhonghua } 8\end{array}$ & $\begin{array}{c}2-6 \text { days } \\
\text { drought }\end{array}$ & $\begin{array}{l}\text { Defense:-superoxide dismutase (SOD), salt-induced protein } \\
\text { (SALT), } \\
\text { Energy metabolism: chloroplast ATPase, RuBisCO small subunit, } \\
\text { RuBisCO large subunit, photosystem II oxygen-evolving complex } \\
\text { protein, oxygen-evolving enhancer protein, light harvesting } \\
\text { complex chain II } \\
\text { Cell structure: Cys peroxiredoxin BAS } 1 \\
\text { Signal transduction: actin depolymerizing factor } \\
\text { Unknown function: serine hydroxymethyltrasferase I, } \\
\text { phosphoglucomutase cytoplasmic }\end{array}$ & [86] \\
\hline $\begin{array}{c}\text { Oryza sativa } \\
\text { L. } \\
\text { Nipponbare, } \\
\text { IR36, } \\
\text { Pokkali }\end{array}$ & $\begin{array}{l}\text { Salinity } \\
50 \mathrm{mM} \\
\mathrm{NaCl}, 24 \mathrm{~h}\end{array}$ & $\begin{array}{c}\text { Energy metabolism: photosystem II oxygen-evolving complex } \\
\text { protein, oxygen evolving enhancer protein (OEE 2), fructose- } \\
\text { bisphosphate aldolases } \\
\text { Antioxidant-superoxide dismutase (SOD) }\end{array}$ & [87] \\
\hline $\begin{array}{l}\text { Oryza sativa } \\
\text { L. } \\
\text { IR 4630-22-2- } \\
5-1-3\end{array}$ & $\begin{array}{l}\text { Salinity } \\
50 \mathrm{mM} \\
\mathrm{NaCl} \\
7 \text { days }\end{array}$ & $\begin{array}{c}\text { RuBisCo activase (RCA): RuBisCO activase } \\
\text { Iron homeostasis: Ferritin, } \\
\text { Energy and metabolism: ATP synthase-putative phosphoglycerate } \\
\text { kinase, } \\
\text { Antioxidant: SOD } \\
\text { Metabolism synthesis: } S \text {-adenosyl-L-methionine synthetase. } \\
\text { Cell cycle: Translation initiation factor 5A }\end{array}$ & [88] \\
\hline $\begin{array}{l}\text { Oryza sativa } \\
\quad \text { L. cv. } \\
\text { Nipponbare }\end{array}$ & $\begin{array}{c}\text { Salinity } \\
150 \mathrm{mM} \\
\mathrm{Nacl}, 24 \mathrm{~h}, \\
48 \mathrm{~h} \text { and } \\
72 \mathrm{~h}\end{array}$ & $\begin{array}{l}\text { Glycolysis enzyme: Triosephosphate isomerase,Enolase Signal } \\
\text { transduction: UDP-glucose pyrophosphorylase (UGPase) Energy } \\
\text { generation: Cytochrome c oxidase subunit } 6 \mathrm{~b}-1 \text { (COX6b-1), } \\
\text { nascent polypeptide-associated complex alpha chain, } \\
\text { S-adenosylmethionine synthetase } 2 \text { Antioxidants: Glutamate } \\
\text { synthetase, Peroxidase Unknown function: Putative actin-binding } \\
\text { protein and putative splicing factor-like protein }\end{array}$ & {$[75]$} \\
\hline $\begin{array}{c}\text { Oryza sativa } \\
\text { L. cv. } \\
\text { Nipponbare } \\
\text { and } \\
\text { Zhonghua } 8\end{array}$ & $\begin{array}{l}\text { Osmotic } \\
\text { Mannitol } \\
400 \mathrm{mM} \\
48 \mathrm{~h}\end{array}$ & $\begin{array}{l}\text { Redox homeostasis: glutathione S-transferase (GST) } \\
\text { Heat shock proteins: heat shock protein, dnaK-type molecular } \\
\text { chaperone, endosperm luminal binding protein (BiP), } \\
\text { Housekeeping: 26S proteasome regulatory subunit, } \\
\text { Signal transduction: calreticulin precursor } \\
\text { Lipid accumulation: lipid transfer protein, } \\
\text { Glyoxalase-glyoxalase I } \\
\text { Proteasome regulatory pathways: 20S proteasome } \alpha \text {-subunit, } \\
\text { proteasome-degradation system-related proteins, endoplasmic } \\
\text { reticulum (ER)-related proteins } \\
\text { Cell death-related protein: uroporphyrinogen decarboxylase }\end{array}$ & [89] \\
\hline
\end{tabular}


Table 2. Cont.

\begin{tabular}{|c|c|c|c|}
\hline Genotype & Treatment & Major result & Reference \\
\hline $\begin{array}{c}\text { Oryza sativa } \\
L .\end{array}$ & $\begin{array}{l}\text { Osmotic } \\
\text { 20\% PEG, } \\
8 \text { days }\end{array}$ & $\begin{array}{c}\text { Redox metabolism; Prx and putative thioredoxin peroxidase } \\
\text { Photosynthesis-rbcS and rbcL } \\
\text { Cytoskeleton stability: putative actin-binding protein, ABP } \\
\text { Defense: putative chitinase } \\
\text { Protein metabolism: ribonuclease } \\
\text { Signal transduction: voltage-dependent anion selective channel } \\
\text { protein and osmotin-like protein }\end{array}$ & {$[90]$} \\
\hline $\begin{array}{l}\text { Oryza sativa } \\
L . \mathrm{cv} \text {. Dongjin }\end{array}$ & $\begin{array}{c}\text { Heat } \\
42{ }^{\circ} \mathrm{C} \text {, for } \\
12 \text { and } \\
24 \mathrm{~h}\end{array}$ & $\begin{array}{l}\text { Heat shock proteins: HSP 70, dnak-type molecular chaperone, } \\
\text { endosperm luminal binding protein (Bip), putative chaperonin } 60 \\
\text { (Cpn 60) precusor } \\
\text { Energy and metabolism: related protein-Transketolase, UDP- } \\
\text { glucose pyrophosphorylase, putative thiamine, pyruvate } \\
\text { dehydrogenase complex (PDC) } \\
\text { Redox homeostasis: GST, dehydro-ascorbate reductase (DHAR), } \\
\text { thioredoxin h-type, SOD } \\
\text { Regulatory proteins/ housekeeping enzymes: chloroplast } \\
\text { elongation factors, cysteine proteinase, proteosome subunit alpha } \\
\text { type1 and subunit of 20s proteosome, nucleoside diphosphate } \\
\text { kinase } 1 \text { (NDPK1) }\end{array}$ & [91] \\
\hline $\begin{array}{c}\text { Oryza sativa } \\
\text { L. ssp. } \\
\text { japonica }\end{array}$ & $\begin{array}{c}\text { Cold } \\
15,10 \text { and } \\
5{ }^{\circ} \mathrm{C} 24 \mathrm{~h}\end{array}$ & $\begin{array}{c}\text { Signal transduction: Elongation factor } \\
\text { Metabolism synthesis: } S \text {-adenosylmethionine synthetase 2, } \\
\text { VB12-independent methionine synthase } \\
\text { Antioxidative: GDP-mannose 3',5'-epimerase } \\
\text { Protein metabolism: chaperonin, ATP-dependent Clp protease } \\
\text { ATP-binding subunit } \\
\text { Oxygen-evolving complex proteins: NADH-ubiquinone } \\
\text { oxidoreductase, putative ferredoxin-NADP(H) oxidoreductase }\end{array}$ & {$[92]$} \\
\hline $\begin{array}{l}\text { Oryza sativa } \\
\text { L. cv. } \\
\text { Nipponbare }\end{array}$ & $\begin{array}{c}\text { Cold } \\
5^{\circ} \mathrm{C} 48 \mathrm{~h}\end{array}$ & $\begin{array}{c}\text { Cellulose synthesis: UDP-glucose pyrophosphorylase } \\
\text { Energy metabolism: adenylate kinase protein, RuBisCO LSU, } \\
\text { vacuolar ATPase B subunit, } \mathrm{H}^{+} \text {transporting ATP synthase, } \\
\text { fructose-bisphosphate aldolase } \\
\text { Protease: cysteine proteinase, } \\
\text { 5-methyltetrahyropteroyltriglutamate-homocysteine S-methyl } \\
\text { transferase, protein disulfide isomerase, } \\
\text { Stress defense: Betaine aldehyde dehydrogenase (salt), } \\
\text { Phenylalanine ammonia lyase (mechanical wounding), } \\
\text { Beta-1,3-glucanases } \\
\text { Signal transduction: Calreticulin, phosphoglycerate kinase, } \\
\text { Elongation factor G } \\
\text { Heat shock protein: HSP70 } \\
\text { Housekeeping enzymes: nucleoside diphosphate kinase (NDPK) } \\
\text { Antioxidant enzymes: superoxide dismutase (Cu/Zn), catalase, } \\
\text { Unknown function: phosphoglucomutase, chitinase III-like } \\
\text { protein, malate dehydrogenase }\end{array}$ & [93] \\
\hline
\end{tabular}


Table 2. Cont.

\begin{tabular}{|c|c|c|c|}
\hline Genotype & Treatment & Major result & Reference \\
\hline $\begin{array}{c}\text { Oryza sativa } \\
\text { L. cv. Dongjin }\end{array}$ & $\begin{array}{c}\text { Cold } \\
5^{\circ} \mathrm{C} 12 \mathrm{~h}, \\
24 \mathrm{~h}, 36 \mathrm{~h} \\
10^{\circ} \mathrm{C} 24 \mathrm{~h} \\
\text { and } 72 \mathrm{~h}\end{array}$ & $\begin{array}{c}\text { Antioxidant enzymes: Ascorbate peroxidase, putative glutathione } \\
S \text {-transferase, thioredoxin } h \text {-type (Thx } h \text { ) and thioredoxin } \\
\text { peroxidase } \\
\text { Housekeeping enzymes: nucleoside diphosphate kinase } 1 \\
\text { (NDPK1) } \\
\text { Lipid-binding protein-fibrillin-like protein } \\
\text { Protease: cysteine proteinase } \\
\text { Regulatory: drought-inducible late embryogenesis abundant } \\
\text { protein, RING zinc finger protein-like }\end{array}$ & [94] \\
\hline $\begin{array}{c}\text { Oryza sativa } \\
\text { L. } \\
\text { Chunyou } 58 \\
\text { and Yongyou } \\
6\end{array}$ & $\begin{array}{c}\text { Nitrogen } \\
\text { Shortage } \\
\text { of } \mathrm{N} \text { for } \\
12 \mathrm{~h}, \\
3 \text { days and } \\
7 \text { days }\end{array}$ & $\begin{array}{l}\text { Photosynthetic metabolism: ribulose-1,5-bisphosphate } \\
\text { carboxylase/oxygenase activase, type II tight-harvesting } \\
\text { chlorophyll a/b-binding protein, carbonic anhydrases, rubisco } \\
\text { large subunit, 23kDa polypeptide of photosystem II, } \\
\text { dTDP-glucose 4-6-dehydratase-like protein and H protein subunit } \\
\text { of glycine decarboxylase 3'-partial } \\
\text { Stress responses/defenses: DegP2, harpin-binding proteins, heat } \\
\text { shock-related proteins, glutathione } S \text {-transferase GSTF14, } \\
\text { Fibrillin-like protein, Glyceraldehyde-3-phosphate dehydrogenase } \\
\text { Membrane transporter: Putative chloroplast inner envelop protein, } \\
\text { SecA protein }\end{array}$ & [95] \\
\hline $\begin{array}{l}\text { Oryza sativa } \\
\text { L. cv. Dongjin }\end{array}$ & $\begin{array}{c}\text { Chemical } \\
\text { treatment } \\
100 \mu \mathrm{M} \\
\mathrm{CdCl}_{2} \text { for } \\
24 \mathrm{~h}\end{array}$ & $\begin{array}{l}\text { Antioxidant enzymes: L-ascorbate peroxidase 1, GR, glutathione } \\
\text { S-transferases, NADH-ubiquinone oxidoreductase, hypothetical } \\
\text { protein, peroxidase, putative ferredoxin-NADP(H) oxidoreductase } \\
\text { Carbohydrate metabolism: Bisphosphoglycerate-independent } \\
\text { phosphoglycerate mutase, glyceraldehyde-3-phosphate } \\
\text { dehydrogenase, Alpha-1,4-glucan-protein synthase, endo-1,3-beta- } \\
\text { glucanase } \\
\text { Amino acids and photosynthesis metabolism: glutamine } \\
\text { synthetase, Photosystem II oxygen-evolving complex protein 2, } \\
\text { ribulose bisphosphate carboxylase/oxygenase activase } \\
\text { Protein metabolism: Putative ubiquitin isopeptidase T, } 26 \mathrm{~S} \\
\text { proteasome, Chloroplast translational elongation factor Tu, } \\
\text { elongation factor P, Putative chaperonin } 60 \text { beta, vacuolar } \\
\text { proton-ATPase, guanine nucleotide-binding protein subunit } \\
\text { beta-like protein, ricin B-related lectin domain-containing protein }\end{array}$ & [96] \\
\hline $\begin{array}{c}\text { Oryza sativa } \\
\text { L. cv. } \\
\text { Nipponbare }\end{array}$ & $\begin{array}{c}\text { Ozone } \\
0.2 \mathrm{ppm} \text {, } \\
24 \mathrm{~h}\end{array}$ & $\begin{array}{l}\text { Cellular processing and signaling: Ion transporters, MAPK, } \\
\mathrm{Ca}^{2+} \text {-dependent protein kinase (CPKs), } \mathrm{Ca}^{2+} \text {-binding proteins, } \\
\text { receptor kinases } \\
\text { Photosynthesis: ATP-dependent Clp protease, chloroplast cell } \\
\text { division protease ftsH homologous, HSP 90, Rubisco } \\
\text { Defense: chloroplast L-APX, glutathione peroxidase, putative } \\
\text { basic secretory protein } \\
\text { Antioxidant: glutathione } S \text {-transferase, glutathione peroxidase, } \\
\text { glutathione reductase, catalase, monodehydroacorbate reductase }\end{array}$ & [68] \\
\hline
\end{tabular}




\section{Rice Metabolomics}

Metabolites are the end products of cellular process and they reflect the response of biological systems to environmental changes [97]. The current trend in metabolomic studies is to define the cellular status at a particular time point by quantification of the total metabolites in the cellular system [98]. These techniques complement other techniques such as transcriptomics and proteomics and depict precise pictures of the whole cellular process. A range of analytical technology is available for plant metabolome study [99], including the use of high throughput approaches such as Fourier transform infrared (FT-IR) [100], ultra high-resolution Fourier transform-ion cyclotron MS [101], gas chromatography-mass spectrometry (GC-MS) [102], and nuclear magnetic resonance (NMR) [103].

Studies on rice metabolomics have so far focused on the quality of metabolites, such as the types of metabolites that can promote seed germination [104], the metabolites variation between mutant and wild type plants [105], the profiling of metabolome at different developmental stages [106], and the observation of natural metabolite variation between rice varieties [107]. Limited information is available on the influence of environmental stresses on rice, except with a few studies reported on stress treatment with drought and salt [108], biotic (bacteria) [109], chemical (Cr.) [110], ozone [68], anaerobic [111], aerobic [112], submergence [113], oxidative [114] and metabolite changes under diurnal cycle [115] (Figure 3). Stress mechanisms have also been reported in other plant species, such as salt stress on tomato [100], nutrient deficiency that led to metabolites shifting in Arabidopsis [101,102,116], metabolite shift in Arabidopsis by temperature stress [102], drought stress on pea [117], biotic stress on opium poppy [118], and drought stress on Thellungiella salsuginea [119]. These studies have pinned down several key metabolism pathways that respond specifically to certain stresses (Figure 4).

In general, the integration pathways (Figures 3 and 4) show that abiotic and biotic stress pathways shifted the normal amino acid biosynthesis pathway, citric acid cycle, and photorespiration pathway. Glutamate, which acts as a stress biomarker, was observed in almost all the stress treatments. Threonine, glutamine, aspartate, isoleucine, and tyrosine were activated in both rice and other species studied (Figures 3 and 4), suggesting the involvement of these molecules in stress adaptation. The huge shifting observed in the amino acids biosynthesis pathway is likely due to the activation of their precursor in the central energy metabolism (observed in proteomics study). Changes in glycolytic activity could affect the availability of carbon for downstream response in amino acid synthesis [114], which may cause protein degradation. However, the changes of metabolites observed in Figures 3 and 4 are reports from various plant types, which may have different tolerance ability towards stress. Moreover, the protein degradation in plants is a complex process involving a multitude of proteolytic pathways. Thus, it remains to be investigated as to whether the accumulation of amino acids observed in all the stresses is a signal of protein degradation. It has also been proven that the accumulation of amino acids was correlated with the blocking of starch production under revert environmental challenge [120]. As starch is the main component for rice grain, reduction of starch content in rice plant could lead to huge losses in rice yield. 
Figure 3. Metabolite changes in rice under biotic stress (bacteria) [109], chemical (Cr.) [110], ozone [68], anaerobic [111], aerobic [112], submergence [113] and metabolite changes under diurnal cycle [115].

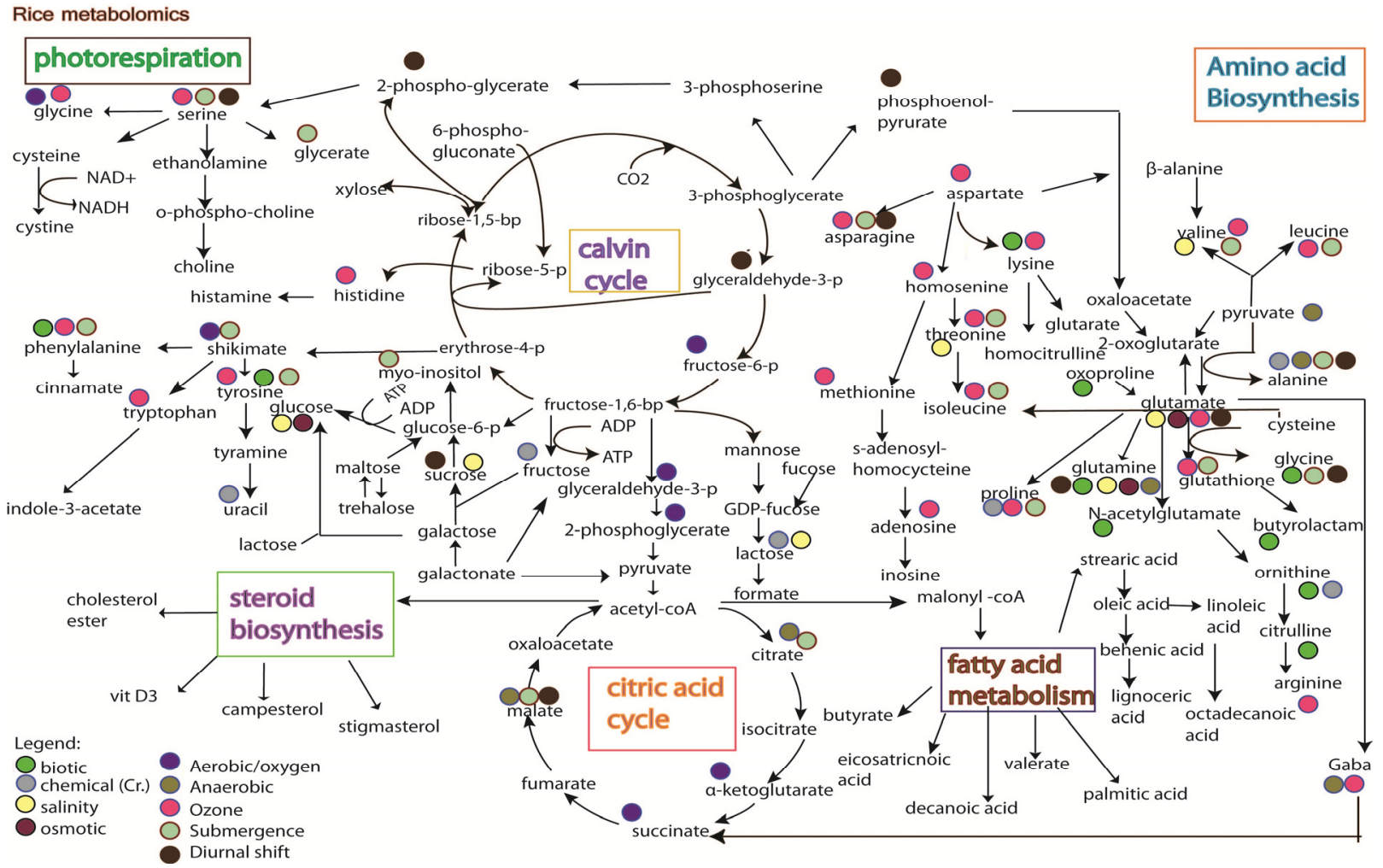

Figure 4. The changes of metabolites under different stress treatments. Results were obtained from treatment with biotic stress [118], drought [117], salinity [116], oxidative stress [121], temperature [102], osmotic stress [119], nutritional stress [101], and combination of stresses [122].

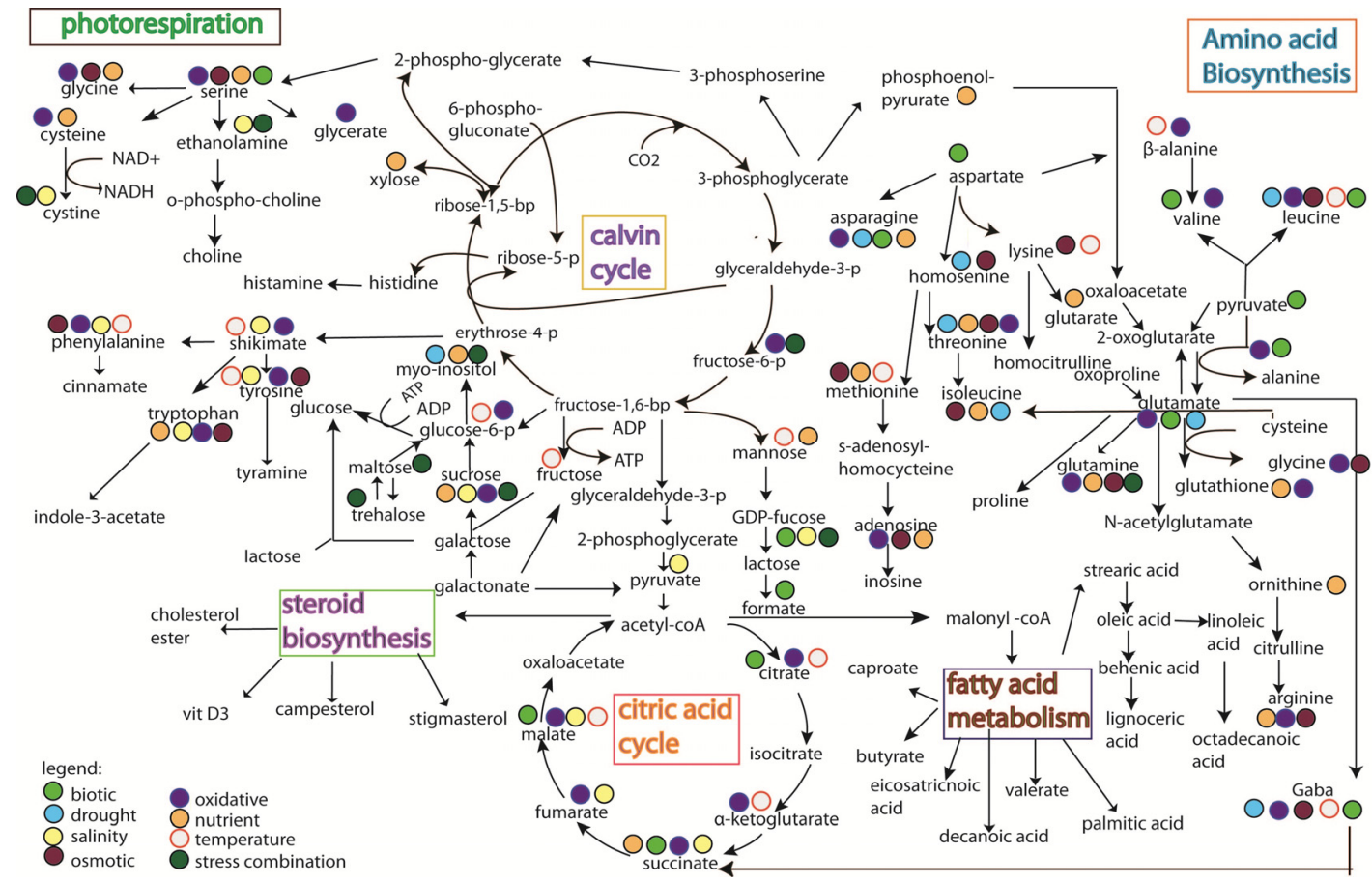


A completely different pattern of metabolomic response was observed when comparing the oxidative response in Arabidopsis with that in rice plant (Figures 3 and 4) and this is likely due to the differences in respect to oxidative stress. For example, submergence could cause less oxygen uptake and accumulation of toxin in plant cells, whereas the treatment of plant cells with methyl viologen (MV) could induce the accumulation of ROS. In addition, biotic stress could cause an oxidative burst to protect plant cells and ozone stress could contribute to the major phytotoxic air pollution. The integration maps (Figures 3 and 4) also indicates that ozone treatment in rice and MV treatment in Arabidopsis seem to induce similar responses. It was also revealed in an Arabidopsis study that 11 out of the 29 metabolites observed under oxidative response were induced by biotic stress. However, the mechanism as to how the biotic stress stimuli leads to oxidative damage remains to be investigated. Nevertheless, similar metabolic pathways (as discussed above) were also observed in rice suspension cultured with overexpressing Bax inhibitor-1 (BI-1) under oxidative stress [114]. Bax inhibitor-1 (BI-1) that functioned as the homologs of mammalian apoptotic machinery mediated the dynamic metabolic changes, including the depletion of the central metabolic pathway, redox imbalance, and accumulation of amino acids [114].

Some key metabolites, e.g., alanine, cysteine, cystine, glucose-6-phosphase, and GDP-fucose, showed obtuse response in rice plant compared to those in other species (Figures 3 and 4). The metabolites observed were found responding to redox activation of plastidic glucose-6-phosphase, which regulates the chloroplast enzyme [123]. Even though these metabolites are not detected in rice, photosynthesis-related proteins were still detected under ozone treatment [68]. Succinate in TCA cycle was also profoundly found under salinity, oxidative, and nutrient stress in Arabidopsis, whereas it was found present only under aerobic stress in rice (Figures 3 and 4). Succinate is well known as an oxidative damage indicator and the accumulation of citrate, observed at the beginning of the TCA cycle, implies the start of oxidative damage by $\mathrm{H}_{2} \mathrm{O}_{2}$. However, the toxicity of citrate accumulation is usually reduced or detoxified by $\alpha$-ketoglutarate in order to reduce the accumulation of succinate [124]. In anaerobic and submergence stress (Figure 3), the recovery of oxidative stress seems to have occurred as no accumulation of succinate can be observed (as shown in Figure 3), yet future work (e.g., proteomic studies) is needed to corroborate this finding. On the contrary, glucose and proline were found regulated in rice plant but not in other plant species under stress conditions. Both glucose and proline are two metabolites that are well known as compatible osmolyte for osmotic adjustment under stress condition. Interestingly, proteomic result shows the regulation of glutamine synthetase [96] that functions in proline production [125].

The development of metabolomics data processing allows the identification of key metabolites that are specific to a stress pathway. However, it remains a difficulty to conclude the role of the specific pathway in certain stress conditions. This is due to the lack of a data profile to demonstrate whether the involved pathway is being up or downregulated. It is envisaged that future work could be performed to study the metabolic flux as a solution to the problem above; the work performed by Lehmann et al. [126], who conducted 13C redistribution analysis to prove the downregulation of glycolysis under oxidative stress treatment, could be a good example.

Another way to effectively identify oxidative stress biomarkers is through the use of stringent statistical validation to analyze the complexity of the multivariate data [127]. However, limited breakthrough is achieved in metabolomics due to several factors: (1) Massive replications of sample 
are needed for data verification due to the complex nature of the biological system that also changes diurnally. (2) Identification of hundreds of metabolites is difficult (especially in complex overlapping spectra) with limited search engines available to date. (3) It is a difficult task to integrate metabolomic data obtained from different analytical approaches, e.g., data from GC-MS and NMR provide different information, thus making the data integration more difficult. Since the integration study of the transcriptomic, proteomic, and metabolomics aspects are needed for the discovery of oxidative stress perception and signaling mechanism, an immediate effort is needed to develop a more powerful database that could provide metabolomics data obtained from different techniques and incorporate novel computational methods for "omic" integration study.

\section{Summary of Omic's Data Set and the Challenge of Integrating Multi-Omic Data Sets}

The results from proteomic studies showed huge overlapping in central metabolism (e.g., Calvin cycle, carbohydrate, and lipid biosynthesis pathway) under drought, salinity, and heat treatment (Table 2). However, different metabolism pathways were found to regulate and adjust under metabolomic level, particularly the photorespiration, amino acid biosynthesis, and citric acid pathway. This is likely due to the involvement of PTM and downstream enzymatic response instead of cellular damage responses, which induce more complex metabolites pathways. This indicates the weakness in the use of proteomic approach (as discussed above) - the proteomic approach assumes that the increase of abundance in protein level is always accompanied by biological active compound, but in reality it may encompass the factors by posttranslational modification, which may modify the activities and characteristics of the proteins. An example to support this is the poor correlation between the protein expression level and the microarray results observed in short-term stress treatment $[128,129]$.

The dynamics of antioxidant response has been observed in the proteomic study; however, the link to its downstream responses is missing. Therefore, the role of the metabolite shifting observed at the metabolomic level is unclear, e.g., are those changes related to the regulation of stress perception, or are the changes just the signal of indicating plant damage as a result of lethal stress? The research of Urbanczyk-Wochniak et al. [130] showed that only 571 out of 26,616 of pair-wise transcript-metabolite correlation analyses showed significant correlation. Therefore it can be concluded that the development of bioinformatics in connecting the response in transcription level to either proteomic or metabolomic changes is yet to be completed.

The rapid progress in omics research has led to more and more data sets being generated across all branches of life sciences studies. Various analytical applications, which are essential for the effective integration of data resources, have been reported in different databases [131,132]. These massive datasets are obtained via four important stages: (i) data generation that involves the generation of raw data, e.g., microarray experiment and DNA chips; (ii) data processing that involves the pre-processing of raw data through the use of a computer method, e.g., baseline correction and cutting out noise spectra in NMR experiment; (iii) data integration that arranges data into a biological meaningful way; and, as the last step, the (iv) data analysis that integrates omics data into a functioning systemic context as a whole [133]. However, recent progress in bioinformatics has indicated that the majority of multi-omic researches are still in the first three stages due to the lack of resources allocated for data integration study [133]. This, however, raises the issue on the validation of single annotations in a 
recent study because the reliability of the data sets should be integrated and tested in order to avoid interpretation of false-positive and false-negative results [134]. The challenge in the integration of omic data analysis has been discussed [135]. It was reported that the major problem arose from the incomplete and diverse form of information available on bioinformatics across many sources of data. Therefore, algorithmic approaches have been proposed as the solution for these problems [136].

Integrative omics-metabolic analysis (IOMA) has been built to integrate proteomic and metabolomic data with genome-scale metabolic models in order to accurately predict the cellular metabolism [137]. Recently, a user-friendly web server, SteinerNet, has been created that enables the integration of high-throughput data from different cellular condition and it has been reported to be able to present the results in a biologically meaningful pathway [138]. However, it was revealed that no data on plants has yet been analyzed by either IOMA or SteinerNet. Nevertheless, the use of graph-based integration method (Ondex) has shown its strength as an alternative method in presenting metabolic pathways and protein-protein integration data in Arabidopsis [139]. There is also a method developed for multidimensional omics data processing called OmicBrowse, which is suitable for plant breeding purposes [140].

It was revealed that the transfer of biomarkers for a crop improvement program is still a process filled with many pitfalls and limitations, and it is mostly limited by structural and scientific factors. Before the application of a potential biomarker for use in agronomy, the potential biomarker should be confirmed and validated using hundreds of specimens and it should also be specific, sensitive, and reproducible. The major problem in the discovery of biomarkers is the low quality of biomarker validation, which could be attributed to:

(1) Weak biomarker characterization and validation strategies;

(2) Limitation of the analytical techniques used. As shown in Figures 3 and 4, it is hard to conclude whether the differences in metabolites identified from the same stress is due to species-specific response, or instead merely reflects the variation between analytical tools, e.g., the use of GC versus the use of NMR;

(3) Difficulty in obtaining highly sensitive and specific biomarkers.

Metabolites may shift in massive amounts even with slight changes of environmental condition. Therefore, new research in biomarkers needs to be performed in order to address the accuracy, precision, and reliability in measuring relevant physiological signs, and to avoid the choosing of false-positive results.

\section{Conclusions}

The stress-adaptation mechanism is a complex system that involves the reaction of several enzymes and also metabolites with multiple overlappings in different cell compartments due to possible discrepancies in tolerance levels. This review presents and discusses mainly the key findings in the development of "omic" technology in rice systems. Unfortunately, despite the marvelous progress shown in bioinformatics, the integration of data outputs from phenome, transcriptome, proteome, and metabolome (e.g., the detection of PTM proteins and metabolic changes) has been found inefficient as of yet. Hence, the recent progress in omic technology shows the discovery of only a part of the 
adaptation system and is yet to be sufficient to tell the whole story of stress functioning and signaling mechanism in plants. Therefore, more resources should be allocated for development of bioinformatics technologies in order to effectively target the right biomarkers for crop improvement.

\section{Acknowledgments}

Authors thank the Ministry of Higher Education Malaysia and Universiti Malaysia Terengganu (UMT) for the financial support under the Young Reseacher Fund.

\section{Conflict of Interest}

The authors declare no conflict of interest.

\section{References}

1. Krishnaiah, K.; Varma, N.G. Changing insect pest scenario in the rice ecosystem-A national perspective. Rice Knowl. Manag. Portal 2011, 1-28.

2. Datta, S.K. Rice improvement through application of biotechnological tools. Rice Knowl. Manag. Portal 2011, 1-35.

3. Redona, E.D. Rice biotechnology for developing countries in Asia. Agric. Biotechnol. 2004, 221-230.

4. Newton, A.C.; Johnson, S.N.; Gregory, P.J. Implications of climate change for diseases, crop yields and food security. Euphytica 2011, 179, 3-18.

5. De Azevedo Neto, A.D.; Prisco, J.T.; Enéas-Filho, J.; Rolim Medeiros, J.V.; Gomes-Filho, E. Hydrogen peroxide pre-treatment induces salt-stress acclimation in maize plants. J. Plant Physiol. 2005, 162, 1114-1122.

6. Cheeseman, J.M. Hydrogen peroxide and plant stress: A challenge relationship. Plant Stress 2007, 1, 4-15.

7. Halliwell, B. Reactive species and antioxidants. Redox biology is a fundamental theme of aerobic life. Plant Physiol. 2006, 141, 312-322.

8. Gadjev, I.; Stone, J.M.; Gechev, T.S. Programmed Cell Death in Plants: New Insights into Redox Regulation and the Role of Hydrogen Peroxide. In International Review of Cell and Molecular Biology; Kwang, W.J., Ed.; Academic Press: Waltham, MA, USA, 2008; Volume 270, pp. $87-144$.

9. Neill, S.J.; Desikan, R.; Clarke, A.; Hurst, R.D.; Hancock, J.T. Hydrogen peroxide and nitric oxide as signalling molecules in plants. J. Exp. Bot. 2002, 53, 1237-1247.

10. Bolwell, G.P.; Wojtaszek, P. Mechanisms for the generation of reactive oxygen species in plant defence-A broad perspective. Physiol. Mol. Plant Pathol. 1997, 51, 347-366.

11. Orozco-Cárdenas, M.L.; Narváez-Vásquez, J.; Ryan, C.A. Hydrogen peroxide acts as a second messenger for the induction of defense genes in tomato plants in response to wounding, systemin, and methyl jasmonate. Plant Cell Online 2001, 13, 179-191.

12. Desikan, R.; Clarke, A.; Hancock, J.T.; Neill, S.J. $\mathrm{H}_{2} \mathrm{O}_{2}$ activates a MAP kinase-like enzyme in Arabidopsis thaliana suspension cultures. J. Exp. Bot. 1999, 50, 1863-1866. 
13. Desikan, R.; Cheung, M.K.; Clarke, A.; Golding, S.; Sagi, M.; Fluhr, R.; Rock, C.; Hancock, J.; Neill, S. Hydrogen peroxide is a common signal for darkness-and ABA-induced stomatal closure in Pisum sativum. Funct. Plant Biol. 2004, 31, 913-920.

14. Desikan, R.; Reynolds, A.; Hancock, J.T.; Neill, S.J. Harpin and hydrogen peroxide both initiate programmed cell death but have differential effects on defence gene expression in Arabidopsis suspension cultures. Biochem. J. 1998, 330, 115-120.

15. Aihong, L.; Wang, Y.; Tang, J.; Xue, P.; Li, C.; Liu, L.; Hu, B.; Yang, F.; Loake, G.J.; Chu, C. Nitric oxide and protein s-nitrosylation are integral to hydrogen peroxide induced leaf cell death in rice. Plant Physiol. 2012, 158, 451-464.

16. Białkowski, K.; Olinski, R. Oxidative damage to plant DNA in relation to growth conditions. Acta Biochim. Polonica 1999, 46, 43-49.

17. Halliwell, B.; Gutteridge, J.M.C. Free Radicals in Biology and Medicine; Oxford University Press: Oxford, UK, 1999.

18. Britt, A.B. DNA damage and repair in plants. Annu. Rev. Plant Physiol. Plant Mol. Biol. 1996, 47, 75-100.

19. Moller, I.M.; Jensen, P.E.; Hansson, A. Oxidative modifications to cellular components in plants. Annu. Rev. Plant Biol. 2007, 58, 459-481.

20. Ghezzi, P.; Bonetto, V. Redox proteomics: Identification of oxidatively modified proteins. Proteomics 2003, 3, 1145-1153.

21. Kukreja, S.; Nandwal, A.; Kumar, N.; Sharma, S.; Unvi, V.; Sharma, P. Plant water status, $\mathrm{H}_{2} \mathrm{O}_{2}$ scavenging enzymes, ethylene evolution and membrane integrity of Cicer arietinum roots as affected by salinity. Biol. Plant. 2005, 49, 305-308.

22. Apel, K.; Hirt, H. Reactive oxygen species: Metabolism, oxidative stress, and signal transduction. Annu. Rev. Plant Biol. 2004, 55, 373-399.

23. Hung, W.-C.; Huang, D.-D.; Chien, P.-S.; Yeh, C.-M.; Chen, P.-Y.; Chi, W.-C.; Huang, H.-J. Protein tyrosine dephosphorylation during copper-induced cell death in rice roots. Chemosphere 2007, 69, 55-62.

24. Keller, R.J.; Halmes, N.C.; Hinson, J.A.; Pumford, N.R. Immunochemical detection of oxidized proteins. Chem. Res. Toxicol. 1993, 6, 430-433.

25. Nguyen, A.; Donaldson, R. Metal-catalyzed oxidation induces carbonylation of peroxisomal proteins and loss of enzymatic activities. Arch. Biochem. Biophys. 2005, 439, 25-31.

26. Vanacker, H.; Sandalio, L.; Jimenez, A.; Palma, J.; Corpas, F.; Meseguer, V.; Gomez, M.; Sevilla, F.; Leterrier, M.; Foyer, C.; et al. Roles for redox regulation in leaf senescence of pea plants grown on different sources of nitrogen nutrition. J. Exp. Bot. 2006, 57, 1735-1745.

27. Peng, S.; Huang, J.; Sheehy, J.E.; Laza, R.C.; Visperas, R.M.; Zhong, X.; Centeno, G.S.; Khush, G.S.; Cassman, K.G. Rice yields decline with higher night temperature from global warming. Proc. Natl. Acad. Sci. USA 2004, 101, 9971-9975.

28. Queval, G.; Hager, J.; Gakiere, B.; Noctor, G. Why are literature data for $\mathrm{H}_{2} \mathrm{O}_{2}$ contents so variable? A discussion of potential difficulties in the quantitative assay of leaf extracts. J. Exp. Bot. 2008, 59, 135-146.

29. Foyer, C.H. Redox sensing and signalling associated with reactive oxygen in chloroplasts, peroxisomes and mitochondria. Physiol. Plant. 2003, 119, 355-364. 
30. Neill, S.; Desikan, R.; Hancock, J. Hydrogen peroxide signalling. Curr. Opin. Plant Biol. 2002, 5, 388-395.

31. Moller, I.M. Plant mitochondria and oxidative stress: Electron transport, NADPH turnover, and metabolism of reactive oxygen species. Annu. Rev. Plant Biol. 2001, 52, 561-591.

32. Asada, K. Production and scavenging of reactive oxygen species in chloroplasts and their functions. Plant Physiol. 2006, 141, 391-396.

33. Sano, S.; Tao, S.; Endo, Y.; Inaba, T.; Hossain, M.A.; Miyake, C.; Matsuo, M.; Aoki, H.; Asada, K.; Saito, K. Purification and cDNA cloning of chloroplastic monodehydroascorbate reductase from spinach. Biosci. Biotechnol. Biochem. 2005, 69, 762-772.

34. Del Rio, L.A.; Sandalio, L.M.; Corpas, F.J.; Palma, J.M.; Barroso, J.B. Reactive oxygen species and reactive nitrogen species in peroxisomes. Production, scavenging, and role in cell signaling. Plant Physiol. 2006, 141, 330-335.

35. Mano, S.; Nishimura, M. Plant Peroxisomes. In Vitamins and Hormones; Gerald, L., Ed.; Academic Press: Waltham, MA, USA, 2005; Volume 72, pp. 111-154.

36. Noctor, G.; de Paepe, R.; Foyer, C.H. Mitochondrial redox biology and homeostasis in plants. Trends Plant Sci. 2007, 12, 125-134.

37. Rhoads, D.M.; Umbach, A.L.; Subbaiah, C.C.; Siedow, J.N. Mitochondrial reactive oxygen species. Contribution to oxidative stress and interorganellar signaling. Plant Physiol. 2006, 141, 357-366.

38. Lherminier, J.; Elmayan, T.; Fromentin, J.R.M.; Elaraqui, K.T.; Vesa, S.; Morel, J.; Verrier, J.-L.; Cailleteau, B.; Blein, J.-P.; Simon-Plas, F.O. NADPH oxidase-mediated reactive oxygen species production: Subcellular localization and reassessment of its role in plant defense. Mol. Plant Microbe Interact. 2009, 22, 868-881.

39. Kawasaki, S.; Borchert, C.; Deyholos, M.; Wang, H.; Brazille, S.; Kawai, K.; Galbraith, D.; Bohnert, H.J. Gene expression profiles during the initial phase of salt stress in rice. Plant Cell 2001, 13, 889-906.

40. Gorantla, M.; Babu, P.; Reddy, L.V.; Reddy, A.; Wusirika, R.; Bennetzen, J.L.; Reddy, A.R. Identification of stress-responsive genes in an indica rice (Oryza sativa L.) using ESTs generated from drought-stressed seedlings. J. Exp. Bot. 2007, 58, 253-265.

41. Yamakawa, H.; Hirose, T.; Kuroda, M.; Yamaguchi, T. Comprehensive expression profiling of rice grain filling-related genes under high temperature using DNA microarray. Plant Physiol. 2007, 144, 258-277.

42. Cheng, C.; Yun, K.-Y.; Ressom, H.; Mohanty, B.; Bajic, V.; Jia, Y.; Yun, S.; de los Reyes, B. An early response regulatory cluster induced by low temperature and hydrogen peroxide in seedlings of chilling-tolerant japonica rice. BMC Genomics 2007, 8, 175.

43. Jung, K.-H.; Dardick, C.; Bartley, L.E.; Cao, P.; Phetsom, J.; Canlas, P.; Seo, Y.-S.; Shultz, M.; Ouyang, S.; Yuan, Q.; et al. Refinement of light-responsive transcript lists using rice oligonucleotide arrays: Evaluation of gene-redundancy. PLoS One 2008, 3, e3337.

44. Rabbani, M.A.; Maruyama, K.; Abe, H.; Khan, M.A.; Katsura, K.; Ito, Y.; Yoshiwara, K.; Seki, M.; Shinozaki, K.; Yamaguchi-Shinozaki, K. Monitoring expression profiles of rice genes under cold, drought, and high-salinity stresses and abscisic acid application using cDNA microarray and RNA gel-blot analyses. Plant Physiol. 2003, 133, 1755-1767. 
45. Nakashima, K.; Tran, L.S.P.; van Nguyen, D.; Fujita, M.; Maruyama, K.; Todaka, D.; Ito, Y.; Hayashi, N.; Shinozaki, K.; Yamaguchi, S.K. Functional analysis of a NAC-type transcription factor OsNAC6 involved in abiotic and biotic stress-responsive gene expression in rice. Plant J. 2007, 51, 617-630.

46. Quan, R.; Hu, S.; Zhang, Z.; Zhang, H.; Zhang, Z.; Huang, R. Overexpression of an ERF transcription factor TSRF1 improves rice drought tolerance. Plant Biotechnol. J. 2010, 8, 476-488.

47. Mukherjee, K.; Choudhury, A.; Gupta, B.; Gupta, S.; Sengupta, D. An ABRE-binding factor, OSBZ8, is highly expressed in salt tolerant cultivars than in salt sensitive cultivars of indica rice. BMC Plant Biol. 2006, 6, 18.

48. Dubouzet, J.G.; Sakuma, Y.; Ito, Y.; Kasuga, M.; Dubouzet, E.G.; Miura, S.; Seki, M.; Shinozaki, K.; Yamaguchi-Shinozaki, K. OsDREB genes in rice, Oryza sativa L., encode transcription activators that function in drought-, high-salt- and cold-responsive gene expression. Plant J. 2003, 33, 751-763.

49. Prashanth, S.; Sadhasivam, V.; Parida, A. Over expression of cytosolic copper/zinc superoxide dismutase from a mangrove plant Avicennia marina in indica Rice var Pusa Basmati-1 confers abiotic stress tolerance. Transgenic Res. 2008, 17, 281-291.

50. Wang, F.-Z.; Wang, Q.-B.; Kwon, S.-Y.; Kwak, S.-S.; Su, W.-A. Enhanced drought tolerance of transgenic rice plants expressing a pea manganese superoxide dismutase. J. Plant Physiol. 2005, $162,465-472$.

51. Tanaka, Y.; Hibino, T.; Hayashi, Y.; Tanaka, A.; Kishitani, S.; Takabe, T.; Yokota, S. Salt tolerance of transgenic rice overexpressing yeast mitochondrial Mn-SOD in chloroplasts. Plant Sci. 1999, 148, 131-138.

52. Nagamiya, K.; Motohashi, T.; Nakao, K.; Prodhan, S.; Hattori, E.; Hirose, S.; Ozawa, K.; Ohkawa, Y.; Takabe, T.; Takabe, T.; et al. Enhancement of salt tolerance in transgenic rice expressing an Escherichia coli catalase gene, kat E. Plant Biotechnol. Rep. 2007, 1, 49-55.

53. Matsumura, T.; Tabayashi, N.; Kamagata, Y.; Souma, C.; Saruyama, H. Wheat catalase expressed in transgenic rice can improve tolerance against low temperature stress. Physiol. Plant. 2002, 116, 317-327.

54. Zhao, F.; Zhang, H. Salt and paraquat stress tolerance results from co-expression of the Suaeda salsa glutathione $S$-transferase and catalase in transgenic rice. Plant Cell Tissue Organ Culture 2006, 86, 349-358.

55. Bonifacio, A.; Martins, M.O.; Ribeiro, C.W.; Fontenele, A.V.; Carvalho, F.E.L.; Margis-Pinheiro, M.; Silveira, J.A.G. Role of peroxidases in the compensation of cytosolic ascorbate peroxidase knockdown in rice plants under abiotic stress. Plant Cell Environ. 2011, 34, $1705-1722$.

56. Sato, Y.; Masuta, Y.; Saito, K.; Murayama, S.; Ozawa, K. Enhanced chilling tolerance at the booting stage in rice by transgenic overexpression of the ascorbate peroxidase gene, OsAPXa. Plant Cell Rep. 2011, 30, 399-406.

57. Kouril, R.; Lazar, D.; Lee, H.; Jo, J.; Naus, J. Moderately elevated temperature eliminates resistance of rice plants with enhanced expression of glutathione reductase to intensive photooxidative stress. Photosynthetica 2003, 41, 571-578. 
58. Takesawa, T.; Ito, M.; Kanzaki, H.; Kameya, N.; Nakamura, I. Over-expression of zeta glutathione $S$-transferase in transgenic rice enhances germination and growth at low temperature. Mol. Breed. 2002, 9, 93-101.

59. Hu, T.; Qv, X.; Xiao, G.; Huang, X. Enhanced tolerance to herbicide of rice plants by over-expression of a glutathione $S$-transferase. Mol. Breed. 2009, 24, 409-418.

60. Olsen, A.N.; Ernst, H.; Leggio, L.L.; Skriver, K. NAC transcription factors: Structurally distinct, functionally diverse. Trends Plant Sci. 2005, 10, 79-87.

61. Hu, H.; Dai, M.; Yao, J.; Xiao, B.; Li, X.; Zhang, Q.; Xiong, L. Overexpressing a NAM, ATAF, and CUC (NAC) transcription factor enhances drought resistance and salt tolerance in rice. Proc. Natl. Acad. Sci. USA 2006, 103, 12987-12992.

62. Ohnishi, T.; Sugahara, S.; Yamada, T.; Kikuchi, K.; Yoshiba, Y.; Hirano, H.; Tsutsumi, N. OsNAC6, a member of the NAC gene family, is induced by various stresses in rice. Genes Genet. Syst. 2005, 80, 135.

63. Ren, Z.-H.; Gao, J.-P.; Li, L.-G.; Cai, X.-L.; Huang, W.; Chao, D.-Y.; Zhu, M.-Z.; Wang, Z.-Y.; Luan, S.; Lin, H.-X. A rice quantitative trait locus for salt tolerance encodes a sodium transporter. Nat. Genet. 2005, 37, 1141-1146.

64. Lu, C.-A.; Ho, T.-H.D.; Ho, S.-L.; Yu, S.-M. Three novel MYB proteins with one DNA binding repeat rediate sugar and hormone regulation of $\alpha$-amylase gene expression. Plant Cell Online 2002, 14, 1963-1980.

65. Su, C.-F.; Wang, Y.-C.; Hsieh, T.-H.; Lu, C.-A.; Tseng, T.-H.; Yu, S.-M. A novel MYBS3-dependent pathway confers cold tolerance in rice. Plant Physiol. 2010, 153, 145-158.

66. Chen, Y.; Yang, X.; He, K.; Liu, M.; Li, J.;Gao, Z.; Lin, Z.; ZHang, Y.; Wang, X.; Qiu, X.; et al. The MYB transcription factor superfamily of Arabidopsis: Expression analysis and phylogenetic comparison with the rice MYB family. Plant Mol. Biol. 2006, 60, 107-124.

67. Gadjev, I.; Vanderauwera, S.; Gechev, T.S.; Laloi, C.; Minkov, I.N.; Shulaev, V.; Apel, K.; Inzé, D.; Mittler, R.; van Breusegem, F. Transcriptomic footprints disclose specificity of reactive oxygen species signaling in Arabidopsis. Plant Physiol. 2006, 141, 436-445.

68. Cho, K.; Shibato, J.; Agrawal, G.K.; Jung, Y.-H.; Kubo, A.; Jwa, N.-S.; Tamogami, S.; Satoh, K.; Kikuchi, S.; Higashi, T.; et al. Integrated transcriptomics, proteomics, and metabolomics analyses to survey ozone responses in the leaves of rice seedling. J. Proteome Res. 2008, 7, 2980-2998.

69. Xu, K.; Xu, X.; Fukao, T.; Canlas, P.; Maghirang-Rodriguez, R.; Heuer, S.; Ismail, A.M.; Bailey-Serres, J.; Ronald, P.C.; Mackill, D.J. Sub1A is an ethylene-response-factor-like gene that confers submergence tolerance to rice. Nature 2006, 442, 705-708.

70. Liu, F.; Xu, W.; Wei, Q.; Zhang, Z.; Xing, Z.; Tan, L.; Di, C.; Yao, D.; Wang, C.; Tan, Y.; et al. Gene expression profiles deciphering rice phenotypic variation between Nipponbare (Japonica) and 93-11 (Indica) during oxidative stress. PLoS One 2010, 5, e8632.

71. Komatsu, S. Rice Proteomics: A Step toward Functional Analysis of the Rice Genome. In Rice Functional Genomics; Springer: New York, NY, USA, 2007; pp. 61-89.

72. Schroeder, J.I.; Kwak, J.M.; Allen, G.J. Guard cell abscisic acid signalling and engineering drought hardiness in plants. Nature 2001, 410, 327-330. 
73. Fukuda, M.; Islam, N.; Woo, S.-H.; Yamagishi, A.; Takaoka, M.; Hirano, H. Assessing matrix assisted laser desorption/ ionization-time of flight-mass spectrometry as a means of rapid embryo protein identification in rice. Electrophoresis 2003, 24, 1319-1329.

74. Chen, X.; Wang, Y.; Li, J.; Jiang, A.; Cheng, Y.; Zhang, W. Mitochondrial proteome during salt stress-induced programmed cell death in rice. Plant Physiol. Biochem. 2009, 47, 407-415.

75. Yan, S.; Tang, Z.; Su, W.; Sun, W. Proteomic analysis of salt stress-responsive proteins in rice root. Proteomics 2005, 5, 235-244.

76. Lee, D.-G.; Ahsan, N.; Lee, S.-H.; Lee, J.J.; Bahk, J.D.; Kang, K.Y.; Lee, B.-H. Chilling stress-induced proteomic changes in rice roots. J. Plant Physiol. 2009, 166, 1-11.

77. Salekdeh, G.H.; Siopongco, J.; Wade, L.J.; Ghareyazie, B.; Bennett, J. Proteomic analysis of rice leaves during drought stress and recovery. Proteomics 2002, 2, 1131-1145.

78. Liu, J.-X.; Bennett, J. Reversible and irreversible drought-induced changes in the anther proteome of rice (Oryza sativa L.) genotypes IR64 and moroberekan. Mol. Plant 2011, 4, 59-69.

79. Rao, S.R.; Ford, K.L.; Cassin, A.M.; Roessner, U.; Patterson, J.H.; Bacic, A. Proteomic and metabolic profiling of rice suspension culture cells as a model to study abscisic acid signaling response pathways in plants. J. Proteome Res. 2010, 9, 6623-6634.

80. Cai, L.; Tu, B.P. Driving the cell cycle through metabolism. Annu. Rev. Cell Dev. Biol. 2012, 28, 59-87.

81. Cuddihy, S.L.; Baty, J.W.; Brown, K.K.; Winterbourn, C.C.; Hampton, M.B. Proteomic detection of oxidized and reduced thiol proteins in cultured cells. Methods Mol Biol. 2008, 519, $363-375$.

82. Baty, J.W.; Hampton, M.B.; Winterbourn, C.C. Detection of oxidant sensitive thiol proteins by fluorescence labeling and two-dimensional electrophoresis. Proteomics 2002, 2, 1261-1266.

83. Fu, C.; Hu, J.; Liu, T.; Ago, T.; Sadoshima, J.; Li, H. Quantitative analysis of redox-sensitive proteome with DIGE and ICAT. J. Proteome Res. 2008, 7, 3789-3802.

84. Koller, A.; Washburn, M.P.; Lange, B.M.; Andon, N.L.; Deciu, C.; Haynes, P.A.; Hays, L.; Schieltz, D.; Ulaszek, R.; Wei, J.; et al. Proteomic survey of metabolic pathways in rice. Proc. Natl. Acad. Sci. USA 2002, 99, 11969-11974.

85. Griffin, T.J.; Sherman, J.; Aebersold, R. Quantitative Proteomics (ICAT ${ }^{\mathrm{TM}}$ ); John Wiley \& Sons Ltd.: Hoboken, NJ, USA, 2001.

86. Ali, G.M.; Komatsu, S. Proteomic analysis of rice leaf sheath during drought stress. J. Proteome Res. 2006, 5, 396-403.

87. Abbasi, F.M.; Komatsu, S. A proteomic approach to analyze salt-responsive proteins in rice leaf sheath. Proteomics 2004, 4, 2072-2081.

88. Parker, R.; Flowers, T.J.; Moore, A.L.; Harpham, N.V.J. An accurate and reproducible method for proteome profiling of the effects of salt stress in the rice leaf lamina. J. Exp. Bot. 2006, 57, 1109-1118.

89. Zang, X.; Komatsu, S. A proteomics approach for identifying osmotic-stress-related proteins in rice. Phytochemistry 2007, 68, 426-437.

90. Xiong, J.-H.; Fu, B.-Y.; Xu, H.-X.; LI, Y.-S. Proteomic analysis of PEG-simulated drought stress-responsive proteins of rice leaves using a pyramiding rice line at the seedling stage. Bot. Studies 2010, 51, 137-145. 
91. Lee, D.-G.; Ahsan, N.; Lee, S.-H.; Kang, K.Y.; Bahk, J.D.; Lee, I.-J.; Lee, B.-H. A proteomic approach in analyzing heat-responsive proteins in rice leaves. Proteomics 2007, 7, 3369-3383.

92. Cui, S.; Huang, F.; Wang, J.; Ma, X.; Cheng, Y.; Liu, J. A proteomic analysis of cold stress responses in rice seedlings. Proteomics 2005, 5, 3162-3172.

93. Makoto, H.; Setsuko, K. Proteomic analysis of rice seedlings during cold stress. Proteomics 2007, 7, 1293-1302.

94. Lee, D.-G.; Ahsan, N.; Lee, S.-H.; Kang, K.Y.; Lee, J.J.; Lee, B.H. An approach to identify cold-induced low-abundant proteins in rice leaf. C. R. Biol. 2007, 330, 215-225.

95. Chen, S.; Zeng, F.; Wu, F.; Ma, W.; Zhang, G. Proteomic analysis of nitrogen stress-responsive proteins in two rice cultivars differing in N utilization efficiency. J. Integr. OMICS 2011, 1, 22.

96. Lee, K.; Bae, D.W.; Kim, S.H.; Han, H.J.; Liu, X.; Park, H.C.; Lim, C.O.; Lee, S.Y.; Chung, W.S. Comparative proteomic analysis of the short-term responses of rice roots and leaves to cadmium. J. Plant Physiol. 2010, 167, 161-168.

97. Royuela, M.; Gonzalez, A.; Gonzalez, E.M.; Arrese-Igor, C.; Aparicio-Tejo, P.M.; Gonzalez-Murua, C. Physiological consequences of continuous, sublethal imazethapyr supply to pea plants. J. Plant Physiol. 2000, 157, 345-354.

98. Hollywood, K.; Brison, D.R.; Goodacre, R. Metabolomics: Current technologies and future trends. Proteomics 2006, 6, 4716-4723.

99. Okazaki, Y.; Saito, K. Recent advances of metabolomics in plant biotechnology. Plant Biotechnol. Rep. 2012, 6, 1-15.

100. Johnson, H.E.; Broadhurst, D.; Goodacre, R.; Smith, A.R. Metabolic fingerprinting of salt-stressed tomatoes. Phytochemistry 2003, 62, 919-928.

101. Hirai, M.Y.; Yano, M.; Goodenowe, D.B.; Kanaya, S.; Kimura, T.; Awazuhara, M.; Arita, M.; Fujiwara, T.; Saito, K. Integration of transcriptomics and metabolomics for understanding of global responses to nutritional stresses in Arabidopsis thaliana. Proc. Natl. Acad. Sci. USA 2004, 101, 10205-10210.

102. Kaplan, F.; Kopka, J.; Haskell, D.W.; Zhao, W.; Schiller, K.C.; Gatzke, N.; Sung, D.Y.; Guy, C.L. Exploring the temperature-stress metabolome of Arabidopsis. Plant Physiol. 2004, 136, 4159-4168.

103. Kim, H.K.; Choi, Y.H.; Verpoorte, R. NMR-based metabolomic analysis of plants. Nat. Protoc. 2010, 5, 536-549.

104. Shu, X.-L.; Frank, T.; Shu, Q.-Y.; Engel, K.-H. Metabolite profiling of germinating rice seeds. J. Agric. Food Chem. 2008, 56, 11612-11620.

105. Wakasa, K.; Hasegawa, H.; Nemoto, H.; Matsuda, F.; Miyazawa, H.; Tozawa, Y.; Morino, K.; Komatsu, A.; Yamada, T.; Terakawa, T.; et al. High-level tryptophan accumulation in seeds of transgenic rice and its limited effects on agronomic traits and seed metabolite profile. J. Exp. Bot. 2006, 57, 3069-3078.

106. Tarpley, L.; Duran, A.; Kebrom, T.; Sumner, L. Biomarker metabolites capturing the metabolite variance present in a rice plant developmental period. BMC Plant Biol. 2005, 5, 8. 
107. Kusano, M.; Fukushima, A.; Kobayashi, M.; Hayashi, N.; Jonsson, P.; Moritz, T.; Ebana, K.; Saito, K. Application of a metabolomic method combining one-dimensional and two-dimensional gas chromatography-time-of-flight/mass spectrometry to metabolic phenotyping of natural variants in rice. J. Chromatogr. B 2007, 855, 71-79.

108. Fumagalli, E.; Baldoni, E.; Abbruscato, P.; Piffanelli, P.; Genga, A.; Lamanna, R.; Consonni, R. NMR techniques coupled with multivariate statistical analysis: Tools to analyse Oryza sativa metabolic content under stress conditions. J. Agron. Crop Sci. 2009, 195, 77-88.

109. Sana, T. Metabolomic and transcriptomic analysis of the rice response to the bacterial blight pathogen Xanthomonas oryzae pv. oryzae. Metabolomics 2010, 6, 451-465.

110. Dubey, S.; Misra, P.; Dwivedi, S.; Chatterjee, S.; Bag, S.; Mantri, S.; Asif, M.; Rai, A.; Kumar, S.; Shri, M.; et al. Transcriptomic and metabolomic shifts in rice roots in response to $\mathrm{Cr}$ (VI) stress. BMC Genomics 2010, 11, 648.

111. Fan, T.W.M. In vivo and in vitro metabolomic analysis of anaerobic rice coleoptiles revealed unexpected pathways. Rus. J. Plant Physiol. 2003, 50, 787-793.

112. Narsai, R.; Howell, K.A.; Carroll, A.; Ivanova, A.; Millar, A.H.; Whelan, J. Defining core metabolic and transcriptomic responses to oxygen availability in rice embryos and young seedlings. Plant Physiol. 2009, 151, 306-322.

113. Barding, G.A.; Béni, S.; Fukao, T.; Bailey-Serres, J.; Larive, C.K. Comparison of GC-MS and NMR for metabolite profiling of rice subjected to submergence stress. J. Proteome Res. 2012, 12, 898-909.

114. Ishikawa, T.; Takahara, K.; Hirabayashi, T.; Matsumura, H.; Fujisawa, S.; Terauchi, R.; Uchimiya, H.; Kawai-Yamada, M. Metabolome analysis of response to oxidative stress in rice suspension cells overexpressing cell death suppressor bax inhibitor-1. Plant Cell Physiol. 2010, $51,9-20$.

115. Sato, S.; Arita, M.; Soga, T.; Nishioka, T.; Tomita, M. Time-resolved metabolomics reveals metabolic modulation in rice foliage. BMC Syst. Biol. 2008, 2, 51.

116. Kim, J.K.; Bamba, T.; Harada, K.; Fukusaki, E.; Kobayashi, A. Time-course metabolic profiling in Arabidopsis thaliana cell cultures after salt stress treatment. J. Exp. Bot. 2007, 58, 415-424.

117. Charlton, A.; Donarski, J.; Harrison, M.; Jones, S.; Godward, J.; Oehlschlager, S.; Arques, J.; Ambrose, M.; Chinoy, C.; Mullineaux, P.; et al. Responses of the pea (Pisum sativum L.) leaf metabolome to drought stress assessed by nuclear magnetic resonance spectroscopy. Metabolomics 2008, 4, 312-327.

118. Zulak, K.; Weljie, A.; Vogel, H.; Facchini, P. Quantitative 1H NMR metabolomics reveals extensive metabolic reprogramming of primary and secondary metabolism in elicitor-treated opium poppy cell cultures. BMC Plant Biol. 2008, 8, 5.

119. Lugan, R.; Niogret, M.F.; Leport, L.; Guégan, J.P.; Larher, F.R.; Savouré, A.; Kopka, J.; Bouchereau, A. Metabolome and water homeostasis analysis of Thellungiella salsuginea suggests that dehydration tolerance is a key response to osmotic stress in this halophyte. Plant J. 2010, 64, 215-229.

120. Yamakawa, H.; Hakata, M. Atlas of rice grain filling-related metabolism under high temperature: joint analysis of metabolome and transcriptome demonstrated inhibition of starch accumulation and induction of amino acid accumulation. Plant Cell Physiol. 2010, 51, 1599. 
121. Baxter, C.J.; Redestig, H.; Schauer, N.; Repsilber, D.; Patil, K.R.; Nielsen, J.; Selbig, J.; Liu, J.; Fernie, A.R.; Sweetlove, L.J. The metabolic response of heterotrophic Arabidopsis cells to oxidative stress. Plant Physiol. 2007, 143, 312-325.

122. Rizhsky, L.; Liang, H.; Shuman, J.; Shulaev, V.; Davletova, S.; Mittler, R. When defense pathways collide. The response of Arabidopsis to a combination of drought and heat stress. Plant Physiol. 2004, 134, 1683-1696.

123. Wenderoth, I.; Scheibe, R.; von Schaewen, A. Identification of the cysteine residues involved in redox modification of plant plastidic glucose-6-phosphate dehydrogenase. J. Biol. Chem. 1997, 272, 26985-26990.

124. Mailloux, R.J.; Beriault, R.; Lemire, J.; Singh, R.; Chenier, D.R.; Hamel, R.D.; Appanna, V.D. The tricarboxylic acid cycle, an ancient metabolic network with a novel twist. PLoS One 2007, 2, e690.

125. Wang, Z.-Q.; Yuan, Y.-Z.; Ou, J.-Q.; Lin, Q.-H.; Zhang, C.-F. Glutamine synthetase and glutamate dehydrogenase contribute differentially to proline accumulation in leaves of wheat (Triticum aestivum) seedlings exposed to different salinity. J. Plant Physiol. 2007, 164, 695-701.

126. Lehmann, M.; Schwarzländer, M.; Obata, T.; Sirikantaramas, S.; Burow, M.; Olsen, C.E.; Tohge, T.; Fricker, M.D.; Møller, B.L.; Fernie, A.R.; et al. The metabolic response of Arabidopsis roots to oxidative stress is distinct from that of heterotrophic cells in culture and highlights a complex relationship between the levels of transcripts, metabolites, and flux. Mol. Plant 2009, 2, 390-406.

127. Trygg, J.; Holmes, E.; Lundstedt, T.R. Chemometrics in metabonomics. J. Proteome Res. 2006, $6,469-479$.

128. Grimplet, J.; Wheatley, M.D.; Jouira, H.B.; Deluc, L.G.; Cramer, G.R.; Cushman, J.C. Proteomic and selected metabolite analysis of grape berry tissues under well-watered and water-deficit stress conditions. Proteomics 2009, 9, 2503-2528.

129. Torres-García, W.; Zhang, W.; Runger, G.C.; Johnson, R.H.; Meldrum, D.R. Integrative analysis of transcriptomic and proteomic data of Desulfovibrio vulgaris: A non-linear model to predict abundance of undetected proteins. Bioinformatics 2009, 25, 1905-1914.

130. Urbanczyk-Wochniak, E.; Luedemann, A.; Kopka, J.; Selbig, J.; Roessner-Tunali, U.; Willmitzer, L.; Fernie, A.R. Parallel analysis of transcript and metabolic profiles: A new approach in systems biology. EMBO Rep. 2003, 4, 989-993.

131. Mochida, K.; Shinozaki, K. Genomics and bioinformatics resources for crop improvement. Plant Cell Physiol. 2010, 51, 497-523.

132. Mochida, K.; Shinozaki, K. Advances in omics and bioinformatics tools for systems analyses of plant functions. Plant Cell Physiol. 2011, 52, 2017-2038.

133. Palsson, B.; Zengler, K. The challenges of integrating multi-omic data sets. Nat. Chem. Biol. 2010, 6, 787-789.

134. Steuer, R. Review: On the analysis and interpretation of correlations in metabolomic data. Brief. Bioinform. 2006, 7, 151-158.

135. Edwards, D.; Batley, J. Plant bioinformatics: from genome to phenome. Trends Biotechnol. 2004, 22, 232-237. 
136. Ge, H.; Walhout, A.J.M.; Vidal, M. Integrating "omic" information: A bridge between genomics and systems biology. Trends Genet. 2003, 19, 551-560.

137. Yizhak, K.; Benyamini, T.; Liebermeister, W.; Ruppin, E.; Shlomi, T. Integrating quantitative proteomics and metabolomics with a genome-scale metabolic network model. Bioinformatics 2010, 26, i255-i260.

138. Tuncbag, N.; McCallum, S.; Huang, S.S.C.; Fraenkel, E. SteinerNet: A web server for integrating "omic" data to discover hidden components of response pathways. Nucleic Acids Res. 2012, 40, W505-W509.

139. Lysenko, A.; Hindle, M.M.; Taubert, J.; Saqi, M.; Rawlings, C.J. Data integration for plant genomics - exemplars from the integration of Arabidopsis thaliana databases. Brief. Bioinform. 2009, 10, 676-693.

140. Toyoda, T.; Mochizuki, Y.; Player, K.; Heida, N.K.; Naohiko; Sakaki, Y. OmicBrowse: A browser of multidimensional omics annotations. Bioinformatics 2007, 23, 524-526.

(C) 2013 by the authors; licensee MDPI, Basel, Switzerland. This article is an open access article distributed under the terms and conditions of the Creative Commons Attribution license (http://creativecommons.org/licenses/by/3.0/). 